\title{
Competencies in Science Teaching
}

LEOPOLD MATHELITSCH ${ }^{1}$

$\approx$ The role of competencies is discussed with respect to science teaching. In particular, competence models from Germany, Switzerland and Austria are presented and compared. A special topical program, 'Competencies in Mathematics and Science Teaching', was started in Austria three years ago. Initial experiences with this program are reported, specifically with regard to how the teachers adopt this new idea of competencies and which kind of support is appreciated. Two aspects of the program are explained in detail: the evaluation of the program and the role of exercises and problems.

Keywords: Competencies; Science teaching; Competence models; Evaluation; Exercises and problems 


\section{Kompetence v poučevanju naravoslovja}

LEOPOLD MatheLitsch

$\approx$ Prispevek obravnava vlogo kompetenc v okviru poučevanja naravoslovja. Predstavljeni in primerjani so predvsem nemški, švicarski in avstrijski modeli kompetenc. V Avstriji je bil pred tremi leti vpeljan poseben tematski program Kompetence $\mathrm{v}$ poučevanju matematike in naravoslovja. $\mathrm{V}$ prispevku so predstavljene prve izkušnje programa, in sicer o tem, kako učitelji sprejemajo nov koncept kompetenc in kakšno podporo pri izvajanju programa potrebujejo. Podrobneje sta predstavljena dva vidika programa: evalvacija programa ter vloga vaj in problemskih nalog.

Ključne besede: kompetence, poučevanje naravoslovja, model kompetenc, vaje in problemske naloge 


\section{Introduction}

'Competencies', 'competence models', and 'standards' have become immensely popular terms, but also relevant issues, at least in the educational systems in German-speaking countries. This may be an outcome of international comparative studies, such as TIMSS and PIRLS (Timss, 2011) or PISA (Pisa, 2009), where the results of the students in these countries were below high expectations, and in some cases even below average. In order to counteract and to overcome this undesired situation, several programs have been initiated: in Germany SINUS (Sinus, 2007) and Science in Context (Parchmann et al., 2006), in Switzerland HarmoS (Harmos, 2009), in Austria IMST (Imst, 2013).

The international studies assess and compare the knowledge, but also the attitudes of students in different fields and at different stages of their education. The result of a certain period of education is thereby measured. This had some influence on the focus of researchers in education as well as that of policy makers. Previously, the curriculum was the main educational directive given to the teacher, stating what had to be taught, and also in some cases, by what means. This was an input-oriented and a teacher-centred approach. Now, the attention turned to the output, i.e. what students should have learnt within a certain period. This is an output-oriented and student-centred construction, very often formulated in terms of competencies and standards.

An overview of this approach and of competence models is given in the next chapter, with a special focus on the science subjects of biology, chemistry and physics. The most important factor in implementing a new idea in an educational system is the teacher. How do teachers adopt this new concept and how do they apply it in their classroom? A thematic program was started in Austria three years ago in order to support teachers in the implementation of competencies, and the third chapter reports on this process. School projects lasting for one year constitute the centre of the thematic program. The projects are proposed and executed by teachers or teams of teachers, and they are supposed to be focused on specific aspects of competencies. Two important components of these projects will be emphasised in Chapters Four and Five: One is on the evaluation of the projects, which is done by the teachers themselves using methods of action research (Altrichter, Posch, \& Somekh, 1993), but also executed by experts in educational research performing comparative studies. The second point concerns the role of problems and exercises, which has become more influential within the context of standards and competencies. Conclusions will round up the paper. 


\section{Competencies, competence models and standards in teaching science}

There are many different definitions of the term 'competence', varying mainly in the broadness of the conception. Traditionally, competencies have been seen in a very general way, like social competencies or learning to learn, sometimes termed 'key competencies'. However, competencies have very often been narrowed down to knowledge and skills in a specific field or subject.

In German-speaking countries, the following definition has found general consensus (Weinert, 2001): 'Competencies are cognitive abilities and skills to solve specific problems, associated with motivational, volitional and social dispositions for using these skills and abilities in variable situations. Former definitions often stopped at the first comma, but there is now common agreement that competencies are more than content knowledge and skills, i.e. they should include the awareness and willingness to use them, and this also in a new context.

Nevertheless, such a definition is decidedly abstract and far from practical application. Therefore, competence models have been constructed: They should concretize the structure of competencies, apply them in different situations (e.g. school subjects), and describe details of the different aspects associated with competencies. With regard to educational purposes, competence models should form a basis for standards and, in this sense, should act also as a link between the abstract definition and concrete problems for students.

It is interesting that the competence models of Germany, Switzerland and Austria for science subjects are rather similar to each other. In particular, they span three dimensions: one is connected to contents; the second one to levels and the third one to skills (see Fig. 1). The discussion of the three dimensions will begin with the parameter 'contents'. It could be argued that the least differences between the three countries would concern this dimension, but this is not the case. In physics, for example, Austria has chosen the traditional way, and the content dimension reflects more or less the syllabus and lists mechanics, electromagnetism, thermodynamics, optics and matter. Germany and Switzerland have defined concepts applying to all three science subjects: In Germany, these are energy, matter, interaction, system, and in Switzerland matter, planet earth, energy, the human body, plants and animals, ecosystems, society and technology. 


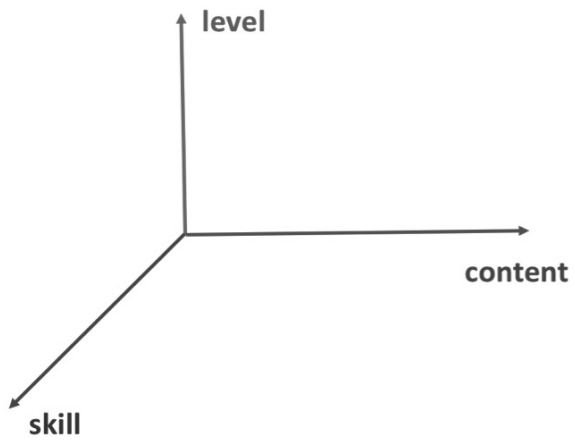

Figure 1. Three-dimensional competence model.

However, the dimension 'level' is the most uniform one: three levels of understanding are defined: reproduction, understanding and application, transfer. There are some differences in the details and the description, but in general the following concepts guide the three levels: reproduction means guided learning and actions, description of phenomena; application should allow for a correct use of the terminology (it should already include some independent work of the students); transfer indicates the ability to connect scientific concepts with real situations in a more-or-less independent way.

The dimension of 'skills' has different subdivisions in the various countries. Austria subsumes different skills and actions in three categories: knowledge organization (collection, presentation, communication of data), gaining cognition (questions, investigations, interpretations), and conclusions (judgment, decision, action) (Bifie, 2011). Germany has four divisions: content knowledge, science methods, communication, and judgment. In Switzerland, several more categories divide this dimension: ask questions and investigate, exploit information sources, organize structure and model, assess and judge, develop and realize, communicate and exchange views (Labudde, Nidegger, Adamina, \& Gingins, 2012).

In principle, one should differentiate between normative versus descriptive competence models. A normative model is a detailed description of aspects of competencies that students should have gained and should have available. A descriptive model, however, is a detailed description of patterns of competencies that the students actually exhibit. Of course, the two models do not coincide in most cases: the first one is an aim, the second one reality. However, the two models should not be too far apart, and therefore an interaction should take place. A descriptive model is based on empirical investigations, and this empirical data must have influence and should be some directive for the normative model. The aim should be ambitious; it should step out from the present 
situation, but it should not be unrealistic. The interaction between normative and empirical models should be a cyclic one.

Standards are indicators for the quality of education in specific situations, i.e. in a given subject, after some period of instruction. They can be related to content (curriculum) or to the performance of the students. Usually they are based on a normative competence model, but they are more specified, tailored to a specific setting. Large-scale assessments take advantage of standards; sometimes standards are established for this purpose. In this sense, the definition of standards should allow for a (more) objective comparison of different groups (classes, schools, countries). Standards are often exemplified by exercises and problems. Because of the importance of this topic, it will be discussed in greater detail in the final chapter.

Standards can be expressed as minimal, regular or even maximal standards. Minimal standards define the least requirements that have to be met by the students. If they score below this level, they usually have to bear consequences. It might be easier to achieve and to agree upon minimal standards than on regular standards, but there is the danger that it could encourage students (and teachers) to be satisfied when this minimal goal is reached. Switzerland has adopted minimal standards (Labudde, 2007).

Regular standards are part of the educational systems in Germany and Austria. They should indicate what the average student should exhibit in content and performance. However, the definition of an average student is exceedingly vague. Regular standards would need empirical studies as a basis. At the present stage, the regular standards in Germany as well as Austria are born out of the common experience of teachers and educators.

Maximal or excellent standards are achievements that only the best students can reach. Usually, they are not implemented in an educational system.

Finally, it should be mentioned that some warning signs and critical remarks on competencies and competence models have already been stated. Schecker (2012) points out that the present way of defining competencies does not provide for a solid basis for describing and measuring learning outcomes. If Weinert's definition as stated above is applied, problems will arise with assessments, since competencies in the above sense can only be measured in a complex setting, including actions and performances of the students.

\section{'Competencies in Mathematics and Science Teaching'}

IMST (Innovations in Mathematics and Science Teaching, Imst, 2013) is an initiative of the Austrian Ministry of Education, a response to the unsatisfying 
performance of Austrian students in the international comparative studies. It started in 1998, and several measures have been initiated and executed in the meantime. For instance, centres for didactics have been founded, nationwide and on a regional basis; networks of teachers also have been installed.

One initiative was the so-called MNI Funds. Teachers were invited to apply for a one-year school-project. The project-proposals underwent a reviewing process, and finally about 100 projects were supported each year. These were new ideas in the Austrian school system: there was a transparent reviewing process; the teachers received a certain amount of money, not only for material but also for their extra work including a final report; teams of supervisors were responsible for different topical groups of projects; the teachers had to attend workshops about evaluations or how to write a report. This program was in action until 2009, which means that in total about 1000 projects were supported.

This program was organized by IMST itself, and the teachers essentially had freedom in their choice of the topic of their proposed project. Three years ago, the structure of this fund was changed: it has been decentralized and also channelled to few specific topics. Institutions within Austria could propose and apply for a so-called thematic or topical program. Out of the 16 applications, five were selected; in the meantime one has been cancelled. The current programs:

- Competencies in Mathematics and Science Teaching

- Competencies in Practical Work

- E-learning and E-teaching

- Reading and Writing

The selection of the topics by the ministry shows the importance that is given to the concept of competencies. The transition from a curriculumdirected to a competence-guided educational system is a declared aim of the ministry. To initiate and support this process, a special institute (Bifie, 2013) was given the assignment and responsibility to develop competence models and standards and to perform nationwide assessments. The thematic programs are another way of supporting and communicating this process. Teachers work for one year on a project related to special aspects of competencies, thereby learning and knowing the topic in depth. At the same time, they are supposed to communicate the outcomes of the project within their school and by a report made public by IMST (IMSTWiki, 2013).

The Regional Centre for Didactics of Physics in Styria applied for the program 'Competencies in Mathematics and Science Teaching'. This centre (pdg, 2013) was founded in 2006 in order to support physics education from pre-school to university. All institutions responsible for physics teacher 
education and in-service training in Styria contribute to this centre: university and technical university, two pedagogical universities and an institution for administration. The centre was awarded the execution of this topical program: the contract includes some financial support, but also the obligation to coach about 20 projects each year, and to combine this process with didactic research. Since the title of the program is 'Competencies in Mathematics and Science Teaching', in order to cover all the topics strong cooperation with the didactic centres of biology, chemistry and mathematics has been established. Since a not negligible number of projects are related with the role of language in science teaching, the centre for didactics on German language has also been asked for support.

Our main purpose was to assist teachers on their way to competenceoriented teaching. Therefore, our research questions are also very much connected to actual school work:

- To which extent do teachers adopt ideas of competence (models)?

- How do they apply these ideas in their teaching?

- How can one support this process?

In 2010/2011, 22 school-projects were allocated to our program; in the following year, 21 were. In summer 2012, 25 projects were approved. The fact that the number of applications went up steadily ( 42 this year) shows that the topic is accepted by the teachers. The next chapter will summarize some results and also document how the program developed in a certain direction.

\section{Evaluation}

The evaluation of the topical program has been executed on two different levels, the first one by the teachers evaluating their own project, the second by researchers in didactics performing cross-case studies. Furthermore, students at the university were involved by choosing some special aspect of the thematic program as a topic of their university thesis.

The evaluation of the projects by the teachers is usually performed by applying methods of action research (Altrichter, Posch, \& Somekh, 1993). Action research is a broad field, but with respect to education one could define it as follows: action research is the study of a special situation in school, performed by teachers, with the aim of improving the quality of the situation. I do not want to discuss here whether action research is research in the traditional way (Herbert Altrichter (1990) entitled a book 'Is this still science?'), but I will compare some characteristics of traditional and action research. This should serve primarily to define action research in greater detail. 
Traditional research is usually a three-step process of data-taking, evaluation and interpretation, whereas action research is often an iterative process of action, evaluation, and action once again. In traditional research, there is a subjectobject relation between the researcher and researched person, whereas in action research a subject-subject relation is taking place. Traditional research consists of a description and explanation of reality. One aim in action research is to change reality, to start a development process. The methods in traditional research are well defined, and should, for example, guarantee reproducibility. Action research allows for a variety of methods with which individual interpretation is essential. The outcome of traditional research is for the scientific community; action research very often should provide feedback only for a single person.

In this sense, action research aims at the personal development of a teacher and/or the improvement of a situation. However, the methods of action research are also a helpful tool for evaluating a project: interviews, questionnaires, analysis of audio- and video-recordings, protocols of observations, evaluation of students' work (tests, home works, portfolios), reflective teaching, and critical friends.

The teachers were supposed to include an evaluation plan in the proposal of their project; a chapter on evaluation also had to be part of the final report. Practice in this respect has shown that evaluation is not a popular part of the project for teachers. Much more effort is invested in the actual work of the project, not in the evaluation. Teachers are not used to such tasks. They also do not see the value of it. Very often they overestimate the results of their evaluation in that they draw general conclusions that are simply not possible because of the small samples. Nevertheless, the constraint to perform such an evaluation opens the awareness of the individual teacher for it, and also generates data for a comparative research.

Cross-case studies were performed for the first two years of the topical program (Knechtl, Rath, \& Rechberger, 2013); the third year is still in process. In particular, we wanted to find answers to the research questions stated in Chapter 3. The basis for the studies consists of questionnaires at the start-up and the following two workshops, the final reports, and phone-interviews with at least one person of each project. Two diploma theses were finished dealing with the program work of the first year, one on the general acceptance of the concept 'competence' by the teachers (Sormann, 2011), the second one on experimental competencies (Lugitsch, 2011). Four more are under way for the second year, but they have not yet been finished.

In the first year, the projects were divided into four groups according to the level of education: science teaching in primary school (7 projects), 
mathematics (5), science subjects in Secondary 1 (6), and science subjects in Secondary 2, including the theme of language and science teaching (4). In total, 59 classes were involved.

The outcome of the first year was, to some extent, uncertain, at least in our opinion. Out of the 22 projects which started at the beginning, 21 were finished, and the teachers executed their projects close to their project plans. Thus, one could say that they fulfilled their tasks. They were also satisfied with their performance and with the support given by the mentors.

The survey at the beginning has shown that the awareness of the conception 'competencies' was unusually low, despite the fact that the teachers have chosen this particular topical program. Final reports and interviews revealed an improvement of their knowledge about competencies and competence models, but the transfer to the classroom took place on only a few occasions. For instance, exercises were still formulated in the traditional way (see the next chapter). Another problem became evident: the topics and methods of the projects were so diverse that it was extremely difficult to compare particular aspects. Therefore, we have chosen a different strategy for the next year.

First, we ordered the 21 projects not according to the age of the students, but with regard to the competence which was most visible in the project plans. The final decision was made in discussion and agreement with the teachers. The new groups were:

- pupils' skills of observation (mainly primary school projects)

- experimental skills

- issues of language in mathematics and science

- students' ability to discuss and judge conflicting issues on a topic.

In addition, we gave the teachers specific tasks: they should attempt to put emphasis on the chosen competence. In particular, one chapter of the final report should be dedicated to one specific example. This example, some exercise, some short school unit, should be connected to this competence, and it should be designed and presented in such a way that other teachers could implement it extremely easily.

The cross-case analysis has been finished; four diploma theses (each one on one of the above mentioned topics) are still under preparation. Teachers again finished their projects successfully, they also appreciated that they had to concentrate on one specific competence. This strengthened their understanding of competences, and they could see an added value to their teaching. Competences were much more visible in the final reports, and about half of the projects included examples in such a quality that they can be used immediately in school. 
This is an encouraging result. We will proceed in this direction, and it could give also a guideline for similar activities, either by policy makers or school authorities: Projects can be a viable way of transferring the idea of competencies to the teacher and, consequently, to the actual school work, but the projects should be centred and concentrated around a few items. The acceptance is much better when the teachers work on a detailed problem in-depth than trying to handle the general topic in a way that is as satisfying as possible.

\section{Problems and exercises}

Analyses of Austrian textbooks have shown that exercises and problems are highly uniform: usually they contain a small calculation imbedded in a context, which is sometimes extremely artificial and unrealistic. Regarding competencies and the three-dimensional span of them (Figure 1), in most cases only a small subspace of the two dimensions 'level' and 'skills' is addressed. For example, the skill 'judgment' is not required in any of the problems. This can be seen also in the results of the PISA tests: those tasks that include elements of judgment had extremely low scores by Austrian students.

The situation may change because of several reasons. The first one is obvious: each country wants to improve in the international tests. Therefore, the previously published examples (some remain unpublished to allow for a comparative study) and similar ones will be used as prototypes for training purposes.

The second reason is connected to competencies and standards. As outlined in Chapter 2, standards indicate in detail what should be known (in the meaning of competencies) at some stage of education. This goal is described in a theoretical way, but always connected with examples, tasks and problems. These exercises can, of course, be used as tests of whether the students have reached this goal, but they also fulfil the purpose of clarifying the intended goal.

A third reason may be initiated by the largest study on the quality of teaching hitherto. John Hattie has performed a synthesis of over 800 metaanalyses (over 50,000 studies) identifying and valuing performance indicators of what makes 'good learning and teaching' (Hattie, 2009, 2011). One of the most positive indicators is the proper feedback, but not only the immediate feedback of the teacher to the student: at least equally significant is the feedback of the students to the teacher. Again, tests, exercises, problems are a valuable tool in this continuing process, but thereby the role of exercises changes substantially. Traditionally, exercises were used as part of final exams or for the preparation of grading-tests. Since the feedback should be permanent and also 
decoupled from grading, tests will fulfil a different purpose, i.e. that mainly students should become aware of their actual standing.

Hand in hand with this process another aspect becomes more and more important: exercises should not only be used as test-instruments or as selfchecks for knowledge and understanding. They can form a valuable method of teaching. Handbooks for driving tests or language-learning very often consist only of a mixture of examples and questions/short exercises. A physics textbook starts with a long explanatory theory finishing with some exercises (endof-chapter-problems). Changing this tradition and creating a different culture of exercises would enrich science education.

Proposals and examples for competence-oriented teaching in science have already been released. A group of experts in the German province of Hessen has published extremely extensive and elaborated examples (Kou, 2013). In all of them, exercises play a substantial role varying between learning problems, exercises for self-evaluation, partner tests, and examinations for grading.

As mentioned in the previous chapter, in the second round of the Austrian topical program the teachers had the explicit task of setting up an extensive problem, i.e. an exercise within their project. Not all of them took up this idea, but the ones who did produced exceptionally creative and interesting examples, and included new elements usually not found in exercises: additional and (for the students) new information, experimental data, promotion of actions, encouragement for discussions among the students, requirement of their opinion and reasons for it. One example is presented in the appendix, centring on judging a chemical commercial product. Collecting the best examples, ordered along the different dimensions of competences, and publishing them electronically is planned.

\section{Conclusions}

With competencies at the centre of an educational system, the focus is directed more on the student than on the teacher or the curriculum. The main question is what did the student learn and understand, and how he or she is able and willing to apply this knowledge for his/her own purposes? This provides a different theoretical framework for education, and competence models should facilitate the connection of the abstract definition with school praxis. Nevertheless, the teacher is the most important player in the educational system and therefore the question of how teachers adopt this new idea and this shift of paradigm is the most crucial one.

This article has given an example of an extensive program in which teachers perform projects dedicated to different aspects of competencies. In 
addition to coaching the projects and to self-evaluation by means of action research, cross-case studies should reveal the acceptance of these new ideas by the teachers, about their way how to handle these new situations, but also how to support this process in a more efficient way.

The experience of the first two years shows that teachers prefer to concentrate on a special aspect of the full problem. Working on one task in detail gives them better insight and understanding of the entire problem. Otherwise, their knowledge of competencies and competence models remained on a theoretical level, and was not translated into actual work in the classroom. The commitment to exercises facilitates the process to a large extent: it broadens the view on different facets of competencies, it makes it easy to embed actual context, and it allows the possibility of continuous feedback between student and teacher.

\section{References}

Altrichter, H., Posch, P., \& Somekh, B. (1993). Teachers Investigate Their Work: An Introduction to the Methods of Action Research. New York: Routledge.

Altrichter, H. (1990). Ist das noch Wissenschaft? München: Profil Verlag.

Bifie (2011). Kompetenzmodell Naturwissenschaften 8. Schulstufe. Retrieved January 92013 from https://www.bifie.at/node/1472

Bifie (2013). Retrieved January 92013 from https://www.bifie.at

Bunderlaa, J. (2012). Naturwissenschaften im täglichen Leben - Kosmetik. Retrieved August 142013 from https://www.imst.ac.at/imst-wiki/images/e/e3/448_Langfassung_Bunderla.pdf Harmos (2009). HarmoS. Retrieved January 92013 from http://www.edk.ch/dyn/11659.php Hattie, J. (2009). Visible Learning - A synthesis of over 800 meta-analysis relating achievement. London, New York: Routledge Chapman \& Hall.

Hattie, J. (2011). Visible Learning for Teachers: Maximizing Impact on Learning. London: Routledge. Imst (2013). IMST. Retrieved January 92013 from https://www.imst.ac.at/ ImstWiki (2013). IMST-Wiki. Retrieved January 92013 from https://www.imst.ac.at/imst-wiki/index. $\mathrm{php} /$ Hauptseite

Knechtl, W., Rath, G., \& Rechberger, V. (2013) Themenprogramm Kompetenzen im Mathematischen und Naturwissenschaftlichen Unterricht, internal report.

Kou (2013). Kompetenzorientiertes Unterrichten. Retrieved January 92013 from www.kou-hessen.d Labudde, P., Nidegger, Ch., Adamina, M., \& Gingins, F. (2012). The Development, Validation and Implementation of Standards in Science Education: Chances and Difficulties in the Swiss Project HarmoS. In S. Bernholt, K. Neumann, \& P. Nentwig (Eds.), Making It Tangible - Learning Outcomes 
in Science Education (pp. 235-259). Münster: Waxmann.

Labudde, P. (2007). How to develop, implement and assess standards in science education. In D.

Waddington, P. Nentwig, \& S. Schanze, Making it Comparable: Standards in Science Education (pp. 277-301). Münster: Waxmann.

Lugitsch, J. (2011). Kompetenzen im experimentellen naturwissenschaftlichen Unterricht, Diploma

Thesis, Univ. Graz. Retrieved January 92013 from http://physicbox.uni-graz.at/bibliothek/

Diplomarbeit_Johannes_Lugitsch.pdf

Parchmann, I., Gräsel, C., Baer, A., Nentwig, P., Demuth, R., \& Ralle, B. (2006). Chemie im Kontext

- a symbiotic implementation of a context-based teaching and learning approach. International

Journal of Science Education, 28(9), 1041-1062.

pdg (2013). Regionales Fachdidaktikzentrum für Physik. Retrieved January 92013 from http://physik.

didaktik-graz.at/

Pisa (2009). PISA Technical report 2009. Retrieved January 92013 from http://www.oecd.org/pisa/ pisaproducts/pisa2009/50036771.pdf

Schecker, H. (2012). Standards, Competencies and Outcomes: A Critical View. In S. Bernholt, K.

Neumann, \& P. Nentwig (Eds.), Making It Tangible - Learning Outcomes in Science Education (pp.

217-234). Münster: Waxmann.

Sinus (2007). SINUS-Transfer. Retrieved January 92013 from http://www.sinus-transfer.de/

Sormann, L. (2011). Umsetzung von Kompetenzen im naturwissenschaftlichen Unterricht,

Diploma Thesis, Univ. Graz. Retrieved January 92013 from http://physicbox.uni-graz.at/bibliothek/

Diplomarbeit_Lisa_Sormann.pdf

Sturmberger, S. (2013). Bewertungskompetenz im naturwissenschafltichen Unterricht, Diploma

Thesis, Univ. Graz. Retrieved August 142013 from http://physicbox.uni-graz.at/bibliothek/

Diplomarbeit_Sandra_Sturmberger.pdf

Timss (2011). TIMSS\&PIRLS. Retrieved at January 92013 from http://timss.bc.edu/

Weinert, F. E. (2001). Concepts of Competence - A Conceptual Clarification. In D. S. Rychen \& L. H.

Salyanik (Eds.), Defining and Selecting Key Competencies (p. 45). Göttingen: Hogrefe und Huber. 


\section{Appendix}

The example is taken from Bunderlaa (2012), and Sturmberger (2013).

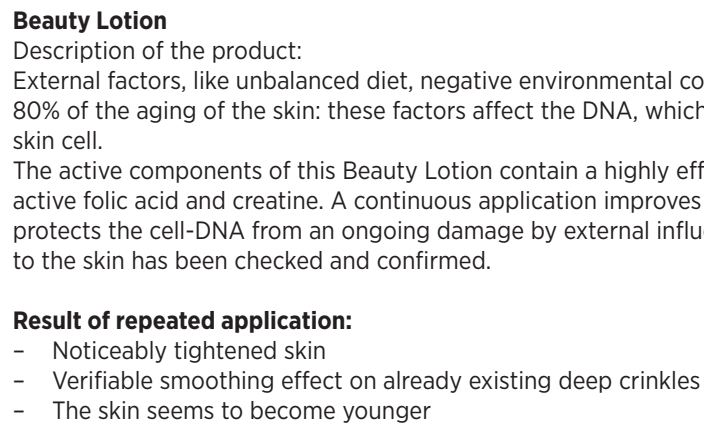

\section{Question 1:}

a) What does the commercial promise?

b) What causes the aging of the skin to a large extent, according to the commercial?

c) The description refers to positive effects against 'damaging factors'. What are the damaging factors?

\section{Questions 2:}

Creatine and folic acid are the effective components according to the commercial. Judge the influence on the human body. How are these components delivered to the body and how well confirmed is their effectiveness as an admixture to cosmetic products?

The following paragraphs of a chemical encyclopaedia (Römpp, Lexikon Chemie, G. Thieme) should help you in answering these questions.

\section{Creatine}

- Component of beef and meat extract stimulating appetite

- Improvement of physical performance with regard to short, intensive activity, provided by nutrition which is enriched with creatine

- Neuroprotective effects for Parkinson and Huntington disease by supply of creatine

- Supply of creatine lowers the plasma level of homocystein and creates positive effects for arteriosclerosis

\section{Folic acid}

Folates are elements of nutrition, mainly in form of pteroylpolyglutamates. They are absorbed in the proximal part of the small intestines with an optimal $\mathrm{PH}$-value of 6 . The human body stores about 5-10 mg, half of it in the liver. The half-life of it is about 100 days. Folates play a central role in the metabolism of amino acids, putins and thymidin.

Demand: The folate balance of a person is maintained by an intake of $400 \mathrm{mg}$ per day in order to avoid symptoms of deficit. A foetus has a higher demand of folic acid; therefore pregnant women should have an intake of $600 \mathrm{mg}$ per day. 
Answer the following questions:

\begin{tabular}{|l|l|l|}
\hline & Creatine & Folic acid \\
\hline $\begin{array}{l}\text { What is the effect of this sub- } \\
\text { stance on the human body? }\end{array}$ & & \\
\hline $\begin{array}{l}\text { How has this substance to be } \\
\text { delivered to the body? }\end{array}$ & & \\
\hline $\begin{array}{l}\text { Is there any proven effect of } \\
\text { this substance with regard to a } \\
\text { cosmetic treatment? }\end{array}$ & & \\
\hline
\end{tabular}

\section{Question 3:}

Is it possible to confirm or contradict the statements in the commercial by scientific methods? If so, by which methods?

\section{Biographical note}

LeOpold MAThelitsch. Education as teacher for physics and mathematics. PhD and habilitation in theoretical particle physics. Research associate at the Texas A\&M University and at the Université Paris Sud. Associate professor at the University of Graz. Head of the Centre for Didactics of Physics in Styria. President of MPTL (Multimedia in Physics Teaching and Learning). Research activities in didactics of physics: interdisciplinary aspects of physics (acoustics, sport), competencies in science education, problem solving, multimedia in teaching physics. (Co)Author of about 200 publications and 20 books, mainly text books for secondary schools. 